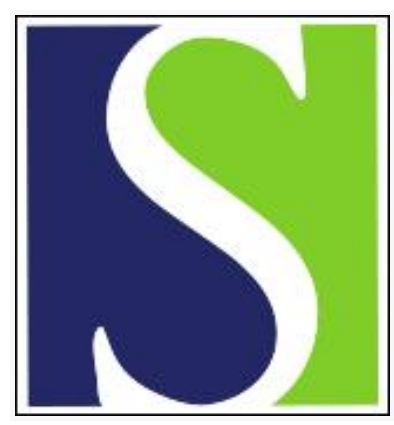

Scand J Work Environ Health 1990;16(4):270-277

https://doi.org/10.5271/sjweh.1785

Issue date: 01 Aug 1990

Respiratory symptoms and lung function of aluminum potroom workers.

by Kongerud J, Gronnesby JK, Magnus P

Affiliation: Department of Thoracic Medicine, Rikshospitalet, University of Oslo, Norway.

This article in PubMed: www.ncbi.nlm.nih.gov/pubmed/2389134






\title{
Respiratory symptoms and lung function of aluminum potroom workers
}

\author{
by Johny Kongerud, MD, ${ }^{1,2}$ Jon Ketil Grønnesby, MA, ${ }^{2}$ Per Magnus, MD ${ }^{2}$
}

\begin{abstract}
KONGERUD J, GRØNNESBY JK, MAGNUS P. Respiratory symptoms and lung function of aluminum potroom workers. Scand J Work Environ Health 1990;16:270-7. The association of occupational exposure with respiratory disease and lung function was examined in a cross-sectional study of 1805 aluminum potroom workers. Work-related asthmatic symptoms occurred in $15 \%$ of the workers with an exposure of 10 years or more and in $8 \%$ of the workers who had been employed less than five years. In a multiple logistic regression analysis an odds ratio (OR) of 3.4 [95\% confidence interval $(95 \% \mathrm{CI})$ 2.1-5.8] for work-related asthmatic symptoms was estimated for long versus short duration of employment. Airflow limitation was also significantly related to years of exposure (OR 2.6, $95 \%$ CI 1.7-3.9). Current occupational exposure and the occurrence of respiratory symptoms were not significantly associated. The results suggest that exposure to air pollutants in the primary aluminum industry may lead to the development of asthmatic symptoms, as well as to reduced respiratory function.
\end{abstract}

Key terms: airway symptoms, aluminum, epidemiology, cross-sectional, occupational exposure.

Aluminum is produced from alumina by electrolytic reduction carried out in smelters. The electrolytic cell in which the reduction takes place is called the pot, and the building is termed the potroom. The pots are of two types, Soderberg and prebake, the latter being more automated and supported to a larger extent by hoods. The emission of polycyclic aromatic hydrocarbons is considerably lower from the prebake pots, while the differences in the average concentrations of other contaminants are small. However, due to intermittent opening of the pots, peak values of pollutants are possibly more prominent for prebake pots. Workers in potrooms are exposed to various air pollutants. Several of these may be related to respiratory disorders. The International Agency for Research on Cancer has listed several contaminants possibly related to respiratory disorders (1). It is likely that the dusts (alumina, cryolite, carbon, and fluorides) together with the fumes and gases (mainly hydrogen fluoride and sulfur dioxide), as well as trace elements like vanadium, chromium, and nickel, could be responsible for respiratory symptoms. However, the association between exposure to the aluminum potroom atmosphere and airway abnormalities remains controversial (2). Occupational asthmatic symptoms among potroom workers in aluminum reduction plants have been reported by some authors $(3-9)$, but not by others $(10-12)$. Whether chronic bronchitis and chronic obstructive lung disease occur in potroom workers as a conse-

${ }^{1}$ Department of Thoracic Medicine, Rikshospitalet, University of Oslo, Oslo 1, Norway.

2 Department of Epidemiology, National Institute of Public Health, Oslo, Norway.

Reprint requests to: Dr J Kongerud, Department of Epidemiology, National Institute of Public Health, Geitmyrsvn 75, N-0462 Oslo 4, Norway. quence of potroom exposure is also controversial (2). Some studies have demonstrated an increased prevalence of chronic bronchitis and lung function abnormalities $(7,10,13)$, while others have not $(11,12)$.

Our report provides the results of a cross-sectional survey of respiratory symptoms and lung function among aluminum potroom workers. We examined the relationship between the outcome variables and potroom exposure while controlling for age, sex, smoking habits, allergy, familial disposition for asthma, and use of airway protection.

\section{Subjects and methods}

A longitudinal study of respiratory symptoms and lung function in a dynamic population of aluminum potroom workers was started on 1 January 1986 . The active work force is examined each year, and all subjects leaving their occupation and new employees are recorded. The present cross-sectional survey was carried out between 1 September and 31 October 1986 and included the active work force in this period.

\section{Subjects}

In seven Norwegian aluminum reduction plants 1679 male and 126 female potroom workers were examined. The survey was a part of the mandatory health program, and complete records were obtained for 1760 subjects $(97.5 \%)$. The median age of the surveyed population was 32 years, and the median duration of employment was 6.5 years (table 1). The women had a shorter duration of exposure than the men on the average, and they constituted only $2.2 \%$ of the group employed 10 years or more. The percentage of never smokers, subjects with allergy, and subjects with a 
Table 1. Characteristics of the aluminum potroom workers by duration of potroom employment. $(\mathrm{N}=$ number of persons in the category, $\%=$ prevalence in employment category)

\begin{tabular}{|c|c|c|c|c|c|c|c|c|c|}
\hline \multirow{2}{*}{$\begin{array}{l}\text { Duration of } \\
\text { employment } \\
\text { (years) }\end{array}$} & \multicolumn{3}{|c|}{ Age (years) } & \multirow[b]{2}{*}{$\begin{array}{c}\text { Males } \\
(\%)\end{array}$} & \multicolumn{3}{|c|}{ Smoking status ${ }^{a}$} & \multirow[b]{2}{*}{$\begin{array}{c}\text { Allergy } \\
(\%)\end{array}$} & \multirow{2}{*}{$\begin{array}{c}\text { Familial } \\
\text { asthma } \\
(\%)\end{array}$} \\
\hline & Median & $\begin{array}{l}\text { Lower } \\
\text { decile }\end{array}$ & $\begin{array}{l}\text { Upper } \\
\text { decile }\end{array}$ & & $\begin{array}{c}\text { Current } \\
\text { smoker } \\
(\%)\end{array}$ & $\begin{array}{c}\text { Ex- } \\
\text { smoker } \\
(\%)\end{array}$ & $\begin{array}{c}\text { Never } \\
\text { smoker } \\
(\%)\end{array}$ & & \\
\hline $\begin{array}{l}0-4(N=662) \\
5-9(N=457) \\
\geq 10(N=641)\end{array}$ & $\begin{array}{l}24 \\
30 \\
47\end{array}$ & $\begin{array}{l}19 \\
24 \\
33\end{array}$ & $\begin{array}{l}38 \\
46 \\
61\end{array}$ & $\begin{array}{l}89.6 \\
90.8 \\
97.8\end{array}$ & $\begin{array}{l}57.9 \\
65.0 \\
59.9\end{array}$ & $\begin{array}{l}10.4 \\
14.0 \\
23.2\end{array}$ & $\begin{array}{l}31.7 \\
21.0 \\
16.8\end{array}$ & $\begin{array}{l}8.9 \\
7.7 \\
5.0\end{array}$ & $\begin{array}{l}16.3 \\
17.3 \\
13.6\end{array}$ \\
\hline Total $(N=1760)$ & 32 & 21 & 55 & 92.9 & 60.5 & 16.0 & 23.5 & 7.2 & 15.6 \\
\hline
\end{tabular}

a Current smokers = persons who had smoked at least one cigarette a day for a year and had not refrained from smoking for one year, ex-smokers = persons who had completely refrained from smoking for at least one year, and never smokers = persons who had never smoked as much as one cigarette a day for a year.

family history of asthma decreased with the number of years employed (table 1).

\section{Assessment of respiratory health effects}

Questionnaires. Respiratory symptoms (dyspnea, wheezing, and cough) during the last year, allergy, familial asthma, asthma prior to potroom employment, smoking habits, and former work exposure were recorded in a self-administered, validated questionnaire (14). Information about the length of employment in the potrooms, duration of symptoms, location and description of the current job, and the use of airway protection was recorded. In a second stage a standardized interview was administered by trained interviewers to subjects reporting symptoms (14). This interview was partly based on the questionnaire of the British Medical Research Council (15) and was supplemented by questions on the occurrence of symptoms on workdays, days of rest, and longer vacations.

Spirometric measurements. Spirometry was carried out with dry, volume-recording spirometers (Jones Pulmonaire at six plants and Vicatest- 4 at one). The spirometers provided automated calculation of the study parameters of interest [forced vital capacity (FVC), and forced expiratory volume in $\left.1 \mathrm{~s}\left(\mathrm{FEV}_{1.0}\right)\right]$. The equipment was volume-calibrated before the start of the survey. Spirometry was performed during the first $4 \mathrm{~h}$ of a dayshift without a noseclip and with the subject standing. The testing procedure followed the recommendations of The American Thoracic Society (16) with a few modifications. FEV 1.0 and FVC were normally taken as the highest values from the first three technically satisfactory forced expirations. The chosen FVC value should not exceed the next highest by more than $0.3 \mathrm{I}$. The measurements were converted to BTPS (body temperature and pressure saturated).

\section{Definitions}

On the basis of questionnaire and interview information, "allergy" was considered to be present if a history of childhood hayfever or atopic eczema was recorded, "never smokers" were lifelong nonsmokers, and "ex-smokers" were those who stopped smoking at least one year before the study. All other subjects were classified as current smokers. The outcome variable of major interest was work-related asthmatic symptoms, defined as dyspnea and wheezing apart from colds with improvement on days of rest or on vacations and with an absence of asthma before employment. The work-related asthmatic symptoms were divided into two groups, simple work-related asthmatic symptoms (without chronic cough) and work-related asthmatic symptoms with chronic cough (ie, workrelated asthmatic symptoms and cough on most days for three consecutive months or more during the year).

We obtained standardized residuals of $\mathrm{FEV}_{1.0}$ $\left(\mathrm{SFEV}_{1.0}\right)$ and FVC (SFVC) by dividing the absolute residual (recorded FEV $_{1.0}$ or FVC minus the predicted) by the residual standard deviation taken from the regression equation used to predict lung function (17). The predicted values were taken from a general population study in Oslo, and the smoking habits in that population were fairly comparable with those of our study population. Standardized residuals have the same scale for all lung function indices and are normally distributed around the mean; hence the age and height bias generally introduced by the percentages of the predicted values are avoided (18). For our purposes we defined airflow limitation as the lower decile of the SFEV $_{1.0}$.

\section{Environmental exposure}

Sampling methods. Measurements of total airborne dust and total fluorides (fluorides in gas and particulate form) were regularly performed with both stationary and personal samplers. In our analyses we have used the results from the personal sampling, which provided the most comparable data between the plants. The figures on exposure are arithmetic means from different jobs or job groups during the year of the survey.

The samplers were standard 37-mm disposable filter cassettes with a $0.8-\mu \mathrm{m}$ pore size for the membrane filter. A backpad was impregnated with sodium formate or potassium hydroxide to absorb gaseous fluo- 
rides. Portable pumps with a minimum capacity of $21 / \mathrm{min}$, automatic flow control, and rechargeable batteries were used. First, the total dust concentration, expressed as milligrams per cubic meter, was calculated from the change in weight of the filter divided by the volume of air sampled. Then the filter (particulate fluorides) and backpad (gaseous fluorides) were separately boiled with $5 \%$ sodium hydroxide to dissolve fluorides. A buffer solution was added, and fluoride was analyzed with specific fluoride electrodes and expressed as milligrams per cubic meter. The sampling was done during 4 to $8 \mathrm{~h}$, and time-weighted average exposures were calculated.

\section{Assessment of exposure}

Current exposure. All plants had standardized their job classification, which consisted of three subdivisions (ie, job department, job group, and job). Even though the work procedures for each job were comparable from plant to plant, the exposure may have varied considerably for the same job at different plants according to the degree of manual operation of the pots, the ventilation systems and hoods, and the type of pot. As a result, the comparison of symptom prevalence between the groups of workers with different exposure was based on the measured level of pollutants rather than on the job titles. However, the exposure measurements were restricted to a few jobs within each job group, and we had to make assumptions about common exposure levels. A total of nine exposure categories were established within each plant. All subjects within the same exposure category and the same type of technology and plant were assigned identical exposure levels as the average of measurements. Subjects working in several types of exposure categories (job rotation) were excluded from the part of the analysis involving current exposure. Thus we were able to estimate the current year's exposure level of total airborne dust (alumina) and total fluorides for 1244 $(69 \%)$ workers with complete data files.

Historical exposure. Historical exposure levels were difficult to estimate on the basis of our measurements, as technical development may have altered both the magnitude of exposure and the inhalable fraction of the pollution. Exposure measurements have only been carried out for a few jobs in the past, and the cost benefit of time-consuming retrospective exposure classification was considered to be low for work-related asthma. It was easy to collect information on the length of potroom employment as a crude estimate of cumulative exposure, and this factor was chosen as the historical exposure index. The subjects were divided into three groups of approximately equal size according to years of potroom employment $(0-4,5-9$, and $\geq 10$ years).

\section{Analysis of the data}

Associations between the outcome variables and the exposure variables were estimated in multivariate models. Multiple regression was used for the continuous dependent variables $\mathrm{SFEV}_{1.0}$ and SFVC. Sex and age were not included in the model, as both were controlled for in the estimation of $\mathrm{SFEV}_{1.0}$ and SFVC. The analysis was performed with the statistical package for the social sciences (SPSS-PC) (19).

Multiple logistic regression was used to model the association between the binary outcome variables and the potential risk factors. (See the appendix.) The models were constructed with the generalized linear interactive modeling (GLIM) system (20). Interaction in the logistic regression model was examined by crossproduct terms of the exposure variables and the extraneous factors. (See the appendix, model 1.) Age and duration of exposure were closely correlated [correlation coefficient $(r)=0.73(P<0.001)$, Spearman's correlation coefficient], and it was not advisable to include these as a cross-product term in the logistic regression analysis (21). Therefore, a stratified analysis to examine any interaction between age and length of exposure was carried out for the outcome variables dyspnea, cough, and work-related asthma. There was no significant difference between the crude odds ratios over the strata, and therefore interaction could probably be disregarded. The cross-product terms did not significantly affect the likelihood estimate. It would appear that interaction in the logistic model could be ignored and cross-product terms eliminated from the final model (appendix, model 3).

Although age and allergy did not change the coefficient of the exposure variables, they were kept in the full model since no improvement in precision was gained by dropping them.

Relative excess risk due to an additive interaction of variables by the method of Rothman (22) was also estimated.

Chi-square analyses on contingency tables were used to examine the relationship between the prevalence of respiratory symptoms and the exposure groups.

\section{Results}

Association between respiratory abnormalities and exposure

The prevalence of respiratory symptoms and diseases is shown in table 2 according to the length of exposure. The percentage of subjects with symptoms increased as the length of employment increased. This trend was the most pronounced for the subjects with simple work-related asthmatic symptoms $(\mathrm{P}<0.001)$, where the prevalence was doubled for the group employed 10 years or more in comparison with that with $0-4$ years of employment (7.6 to $15 \%$ ). All three groups of subjects had negative mean values for the standardized residuals of $\mathrm{FEV}_{1.0}\left(\mathrm{SFEV}_{1.0}\right)$ (table 2). This 
Table 2. Prevalence of respiratory disabilities among the aluminum potroom workers according to duration of employment. $(\mathrm{N}=$ number of persons in the category, $\%=$ symptom prevalence in the employment category)

\begin{tabular}{|c|c|c|c|c|c|c|c|c|}
\hline \multirow[b]{2}{*}{$\begin{array}{l}\text { Duration of } \\
\text { employment } \\
\text { (years) }\end{array}$} & \multirow[b]{2}{*}{$\underset{(\%)}{\text { Cough }}$} & \multirow[b]{2}{*}{$\begin{array}{l}\text { Dyspnea } \\
(\%)\end{array}$} & \multicolumn{2}{|c|}{$\begin{array}{l}\text { Work-related asthmatic } \\
\text { symptoms }\end{array}$} & \multicolumn{2}{|c|}{$\operatorname{SFEV}_{1.0^{a}}$} & \multicolumn{2}{|c|}{ SFVCb } \\
\hline & & & $\begin{array}{c}\text { Without } \\
\text { chronic } \\
\text { cough } \\
(\%)\end{array}$ & $\begin{array}{l}\text { With } \\
\text { chronic } \\
\text { cough } \\
(\%)\end{array}$ & Mean & SD & Mean & SD \\
\hline $\begin{array}{l}0-4(\mathrm{~N}=662) \\
5-9(\mathrm{~N}=457) \\
\geq 10(\mathrm{~N}=641)\end{array}$ & $\begin{array}{l}18.4 \\
23.2 \\
28.4\end{array}$ & $\begin{array}{l}24.0 \\
32.6 \\
38.5\end{array}$ & $\begin{array}{r}7.6 \\
9.4 \\
15.0\end{array}$ & $\begin{array}{l}2.0 \\
5.0 \\
4.1\end{array}$ & $\begin{array}{l}-0.36 \\
-0.59 \\
-0.61\end{array}$ & $\begin{array}{l}0.92 \\
1.03 \\
1.07\end{array}$ & $\begin{array}{l}-0.05 \\
-0.05 \\
-0.04\end{array}$ & $\begin{array}{l}0.95 \\
1.07 \\
1.05\end{array}$ \\
\hline Total $(\mathrm{N}=1760)$ & 23.3 & 31.5 & 10.7 & 3.5 & -0.51 & 1.01 & -0.05 & 1.05 \\
\hline
\end{tabular}

a SFEV . $_{1.0}=\left(\right.$ recorded FEV 1.0 - predicted)/RSD, where $\mathrm{FEV}_{1.0}$ is the forced expiratory volume in $1 \mathrm{~s}$ and RSD is the residual standard deviation from the regression equation used for the prediction values (16).

b $S F V C=$ standardized FVC (forced vital capacity).

result indicates that the mean observed level of $\mathrm{FEV}_{1.0}$ was lower than that predicted when adjusted for age and height. Airflow limitation seemed to increase with increased length of employment. In a multiple regression model with $\mathrm{SFEV}_{1.0}$ as the dependent variable and duration of employment and smoking status (ever smoker and never smoker) as the independent variables, a significant association was found between SFEV $_{1.0}$ and years of exposure (table 3). Smoking was also a significant predictor for $\mathrm{SFEV}_{1,0}$, whereas SFVC was not influenced by any of these determinants.

The logistic regression analysis shown in table 4 confirmed that the risk for work-related asthmatic symptoms increased with length of exposure when sex, age, familial disposition for asthma, allergy, smoking, and use of airway protection were controlled for. The odds ratio for asthmatic symptoms was $3.44(95 \%$ CI 2.06-5.76) for workers employed 10 years or more in comparison those exposed less than five years. Airflow limitation, defined as the lower decile of the $\mathrm{SFEV}_{1.0}$, was also significantly associated with years exposed with an odds ratio of 2.24 (95 \% CI 1.44$3.47)$ and 2.55 (95\% CI 1.68-3.85) for intermediate and long exposure, respectively. Work-related asthmatic symptoms with chronic cough was the only outcome variable significantly related to age (OR 1.04, $95 \% \mathrm{CI} 1.01-1.07)$. The role of present smoking as a predictor for cough (OR 1.95, 95\% CI 1.43-2.67), asthmatic symptoms (OR $1.58,95 \%$ CI 1.05-2.37), and airflow limitation (OR 2.03, $95 \%$ CI 1.28-3.21) was confirmed, whereas earlier smoking did not account for an increased risk of airway abnormality. Allergy provided no significant risk for respiratory symptoms and was negatively correlated to airflow limitation. Reporting of a family history of asthma was slightly, although significantly, related to dyspnea (OR 1.53, $95 \%$ CI 1.14-2.06) and work-related asthmatic symptoms (OR 1.64, $95 \%$ CI 1.08-2.49). The use of respirators was related to each of the outcome variables with all odds ratios larger than 1.4 and was highest for the subjects with work-related asthmatic symptoms (OR 2.89, $95 \%$ CI 1.66-5.02). However,
Table 3. Multiple regression analysis with standardized residuals of the forced expiratory volume in $1 \mathrm{~s}\left(\mathrm{SFEV}_{1.0}\right)$ and the forced vital capacity (SFVC) as the dependent variables and current smoker and duration of potroom employment (in years) as the predictor variables, with the regression coefficient and their standard errors (SE).

\begin{tabular}{lccccc}
\hline & \multicolumn{3}{c}{ Predictor variable } \\
\cline { 2 - 3 } $\begin{array}{l}\text { Dependent } \\
\text { variable }\end{array}$ & \multicolumn{2}{c}{ Current smoker } & & Employment duration \\
\cline { 2 - 3 } \cline { 5 - 6 } & Coefficient & $\begin{array}{c}\text { SE of the } \\
\text { coefficient }\end{array}$ & & Coefficient & $\begin{array}{c}\text { SE of the } \\
\text { coefficient }\end{array}$ \\
\hline SFEV $_{1.0}$ & $-0.21^{* * *}$ & 0.06 & & $-0.11^{\star * *}$ & 0.03 \\
SFVC & 0.00 & 0.06 & & 0.09 & 0.03 \\
\hline
\end{tabular}

$* * * P<0.001$.

the estimates of the odds ratios did not reach significant levels for work-related asthmatic symptoms with chronic cough or airflow limitation.

Mean dust and fluoride exposure during the last year, as well as type of technology, was not significantly associated with any of the outcome variables (table 5). A similar analysis for 460 pot operators with a potroom-specific exposure classification also failed to reach the level of significance for the continuous values of fluoride and dust, OR $1.19(95 \% \mathrm{CI} 0.51-$ 2.81 ) and OR 1.05 (95\% CI 0.80-1.37), respectively. Furthermore, current exposure did not influence the coefficient of the exposure duration, and its possible role as confounder could be disregarded.

\section{Exposure characterization}

The Norwegian hygienic standards for total fluoride and total dust are 2.5 and $5.0 \mathrm{mg} / \mathrm{m}^{3}$, respectively. The 90th percentile for the fluoride measurements was only half of the hygienic standards, while the 90th percentile for total dust was above the permissible level (table 6). However, the amount of fluorides in the work atmosphere correlated negatively with duration of employment $[\mathrm{r}=-0.21(\mathrm{P}<0.001)$, Spearman's correlation], while the level of total dust exposure did not $(\mathrm{r}=0.0)$. 
Table 4. Multiple logistic models for different risk factors related to the respiratory symptoms and lung function of the aluminum potroom workers. The zero value of the dependent variables cough, dyspnea, work-related asthmatic symptoms without chronic cough, and work-related asthmatic symptoms with chronic cough is "no respiratory symptoms." (OR = adjusted odds ratio estimated from the final model of the logistic regression analyses (appendix l, model 3), $95 \% \mathrm{Cl}=$ confidence interval)

\begin{tabular}{|c|c|c|c|c|c|c|c|c|c|c|}
\hline \multirow{4}{*}{$\begin{array}{l}\text { Independent } \\
\text { variables }\end{array}$} & \multicolumn{10}{|c|}{ Dependent variables } \\
\hline & \multirow{2}{*}{\multicolumn{2}{|c|}{ Cough }} & \multirow{2}{*}{\multicolumn{2}{|c|}{ Dyspnea }} & \multicolumn{4}{|c|}{ Work-related asthmatic symptoms } & \multirow{2}{*}{\multicolumn{2}{|c|}{$\begin{array}{c}\text { Airflow } \\
\text { limitationa }\end{array}$}} \\
\hline & & & & & \multicolumn{2}{|c|}{$\begin{array}{l}\text { Without chronic } \\
\text { cough }\end{array}$} & \multicolumn{2}{|c|}{$\begin{array}{l}\text { With chronic } \\
\text { cough }\end{array}$} & & \\
\hline & OR & $95 \% \mathrm{Cl}$ & OR & $95 \% \mathrm{Cl}$ & OR & $95 \% \mathrm{Cl}$ & OR & $95 \% \mathrm{Cl}$ & OR & $95 \% \mathrm{Cl}$ \\
\hline Sex male & 0.74 & $0.47-1.16$ & 0.76 & $0.50-1.16$ & 1.17 & $0.57-2.39$ & 0.40 & $0.17-0.93$ & & $\cdot$ \\
\hline Age & 1.00 & $0.99-1.02$ & 1.01 & $1.00-1.03$ & 1.00 & $0.98-1.01$ & 1.04 & $1.01-1.07$ & & · \\
\hline Familial asthma & 1.57 & $1.14-2.16$ & 1.53 & $1.14-2.06$ & 1.64 & $1.08-2.49$ & 2.54 & $1.39-4.65$ & 1.01 & $0.65-1.56$ \\
\hline Allergy & 1.20 & $0.75-1.91$ & 1.42 & $0.94-2.16$ & 1.38 & $0.76-2.52$ & 0.43 & $0.10-1.88$ & 0.39 & $0.16-0.96$ \\
\hline \multicolumn{11}{|l|}{ Smoking status ${ }^{b}$} \\
\hline $\begin{array}{l}\text { Never smoker } \\
\text { Ex-smoker } \\
\text { Current smoker }\end{array}$ & $\begin{array}{l}1.00 \\
1.31 \\
1.95\end{array}$ & $\begin{array}{l}0.87-1.98 \\
1.43-2.67\end{array}$ & $\begin{array}{l}1.00 \\
1.35 \\
1.96\end{array}$ & $\begin{array}{c}. \\
0.94-1.95 \\
1.48-2.60\end{array}$ & $\begin{array}{l}1.00 \\
1.14 \\
1.58\end{array}$ & $\begin{array}{l}0.67-1.95 \\
1.05-2.37\end{array}$ & $\begin{array}{l}1.00 \\
2.23 \\
4.45\end{array}$ & $\begin{array}{l}0.73-6.81 \\
1.73-11.41\end{array}$ & $\begin{array}{l}1.00 \\
1.07 \\
2.03\end{array}$ & $\begin{array}{l}. \\
0.58-1.97 \\
1.28-3.21\end{array}$ \\
\hline \multicolumn{11}{|l|}{ Years exposed } \\
\hline $\begin{array}{l}0-4 \\
5-9 \\
\geq 10\end{array}$ & $\begin{array}{l}1.00 \\
1.44 \\
2.24\end{array}$ & $\begin{array}{c}1.04-2.00 \\
1.52-3.31\end{array}$ & $\begin{array}{l}1.00 \\
1.48 \\
2.00\end{array}$ & $\begin{array}{c}1.10-1.99 \\
1.40-2.84\end{array}$ & $\begin{array}{l}1.00 \\
1.56 \\
3.44\end{array}$ & $\begin{array}{l}0.98-2.47 \\
2.06-5.76\end{array}$ & $\begin{array}{l}1.00 \\
2.36 \\
1.74\end{array}$ & $\begin{array}{c}1.11-5.00 \\
0.71-4.29\end{array}$ & $\begin{array}{l}1.00 \\
2.24 \\
2.55\end{array}$ & $\begin{array}{l}1.44-3.47 \\
1.68-3.85\end{array}$ \\
\hline \multicolumn{11}{|l|}{$\begin{array}{l}\text { Use of airway } \\
\text { protection }\end{array}$} \\
\hline $\begin{array}{l}\text { Never } \\
\text { Certain jobs } \\
\text { Always }\end{array}$ & $\begin{array}{l}1.00 \\
1.72 \\
1.77\end{array}$ & $\begin{array}{c}\cdot \\
1.21-2.45 \\
1.22-2.56\end{array}$ & $\begin{array}{l}1.00 \\
1.73 \\
1.98\end{array}$ & $\begin{array}{c}\cdot \\
1.26-2.39 \\
1.42-2.78\end{array}$ & $\begin{array}{l}1.00 \\
2.41 \\
2.89\end{array}$ & $\begin{array}{l}1.41-4.11 \\
1.66-5.02\end{array}$ & $\begin{array}{l}1.00 \\
1.78 \\
2.25\end{array}$ & $\begin{array}{l}0.78-4.05 \\
0.95-5.32\end{array}$ & $\begin{array}{l}1.00 \\
1.47 \\
1.62\end{array}$ & $\begin{array}{c}0.91-2.35 \\
0.98-2.65\end{array}$ \\
\hline
\end{tabular}

a Subjects with SFEV ${ }_{10}$ values lower than the 10 th percentile were considered to have a limited airflow. (SFEV $1.0=($ recorded FEV $1.0-$ predicted) $/ \mathrm{RSD}$ where FEV 1.0 is the forced expiratory volume in $1 \mathrm{~s}$ and RSD is the residual standard deviation from the regression equation used for the prediction values.

b A never smoker had never smoked as much as one cigarette a day for a year; an ex-smoker had completely refrained from smoking for at least one year; a current smoker had smoked at least one cigarette a day for a year and had not refrained from smoking for one year.

Table 5. Effect of electrolytic technology and the total dust and total fluoride exposure during the year of the study on cough and work-related asthmatic symptoms. $(O R=$ adjusted odds ratios, $95 \% \mathrm{Cl}=95 \%$ confidence interval)

\begin{tabular}{|c|c|c|c|c|}
\hline & \multicolumn{2}{|c|}{ Cough } & \multicolumn{2}{|c|}{$\begin{array}{l}\text { Work-related } \\
\text { asthmatic } \\
\text { symptoms }\end{array}$} \\
\hline & $\overline{O R^{a}}$ & $95 \% \mathrm{Cl}$ & $\overline{\mathrm{OR}^{a}}$ & $95 \% \mathrm{Cl}$ \\
\hline \multicolumn{5}{|l|}{ Technology } \\
\hline $\begin{array}{l}\text { Soderberg } \\
\text { Prebake }\end{array}$ & $\begin{array}{l}1.22 \\
1.00\end{array}$ & $0.89-1.68$ & $\begin{array}{l}1.16 \\
1.00\end{array}$ & $0.83-1.61$ \\
\hline Total dust exposure ${ }^{b}$ & $1 . i 3$ & $0.80-1.59$ & 1.34 & $0.92-1.96$ \\
\hline Total fluoride exposure & 0.77 & $0.55-1.08$ & 0.90 & $0.62-1.29$ \\
\hline
\end{tabular}

a Estimated from the logistic regression model of the form shown in the appendix (model 2).

- Analyzed as a continuous variable.

Table 6. Average exposure during the year of the study in aluminum potroom workers according to years of employment.

\begin{tabular}{|c|c|c|c|c|c|c|}
\hline \multirow{2}{*}{$\begin{array}{l}\text { Duration } \\
\text { of } \\
\text { employment } \\
\text { (years) }\end{array}$} & \multicolumn{3}{|c|}{ Total fluorides $\left(\mathrm{mg} / \mathrm{m}^{3}\right)$} & \multicolumn{3}{|c|}{ Total dust $\left(\mathrm{mg} / \mathrm{m}^{3}\right)$} \\
\hline & Median & $\begin{array}{l}\text { Lower } \\
\text { decile }\end{array}$ & $\begin{array}{l}\text { Upper } \\
\text { decile }\end{array}$ & Median & $\begin{array}{l}\text { Lower } \\
\text { decile }\end{array}$ & $\begin{array}{l}\text { Upper } \\
\text { decile }\end{array}$ \\
\hline $\begin{array}{l}0-4 \\
5-9 \\
\geq 10\end{array}$ & $\begin{array}{l}0.72 \\
0.53 \\
0.60\end{array}$ & $\begin{array}{l}0.45 \\
0.30 \\
0.37\end{array}$ & $\begin{array}{l}1.37 \\
1.25 \\
0.99\end{array}$ & $\begin{array}{l}3.27 \\
2.90 \\
2.91 \\
\end{array}$ & $\begin{array}{l}1.80 \\
0.90 \\
1.26\end{array}$ & $\begin{array}{l}5.60 \\
6.37 \\
6.37 \\
\end{array}$ \\
\hline Total & 0.63 & 0.40 & 1.25 & 3.25 & 1.26 & 6.37 \\
\hline
\end{tabular}

\section{Interaction}

Additive interaction was assessed between 10 years or more of exposure and smoking with work-related asthmatic symptoms as the outcome variable. No relative excess risk due to interaction (relative excess risk -0.03 ) was found.

\section{Discussion}

\section{Prevalence of work-related asthmatic symptoms}

We found that $10.7 \%$ of the workers reported workrelated asthmatic symptoms. Our results provide support for the existence of asthmatic symptoms as an occupational health problem in the primary aluminum industry. This finding is consistent with the results of a study by Sarić et al (23), who found that $10.2 \%$ of a group of potroom workers complained of dyspnea and wheezing in the chest. However, Chan-Yeung et al (10) did not find asthmatic cases among potroom workers in a cross-sectional survey of aluminum plant workers in British Columbia, although they found a significantly lower prevalence of cough and wheezing, and a higher mean $\mathrm{FEV}_{1.0}$ in the reference group. They also failed to show any association between duration of potroom exposure and respiratory symptoms. Generally speaking, there has been a lower prevalence of asthma reported in North American studies than in European investigations. This difference is unexplained but could be related to different preemployment criteria, prevailing climatic conditions, and differences in exposure intensities. The routines of various plants in respect to the relocation of workers with respiratory complaints may vary and therefore could have produced different results in different cross-sectional studies. Another reason why some 
cross-sectional studies discover "potroom asthma" while others do not could be the geographic location of the plants. In Norway the majority of aluminum plants are situated in isolated parts of the country where few other jobs are available. Thus "settled" workers may neglect symptoms more often than workers living in areas with a more differentiated labor market. We found that $5.3 \%$ of the persons who were potroom workers on 1 January 1986 were no longer in the potrooms one year later, while Discher \& Breitenstein (12) reported that $8.4 \%$ of a potroom work force in the United States and Canada had left in one year. Furthermore, the failure of Chan-Yeung and her co-workers (10) to demonstrate potroom asthma might well be explained by the fact that, prior to the study, five workers had left the potroom due to asthma. Some of the differences between surveys may also be attributed to varying definitions of asthma or to the use of nonstandardized questionnaires.

\section{Association between respiratory symptoms and exposure}

Potroom exposure of 10 years or more, current smoking, and a family history of asthma were associated with respiratory symptoms and transient work-related asthmatic symptoms in this cross-sectional study. Other studies have not been able to show any relationship between symptoms and duration of employment (10, 24). This discrepancy could be due to differences in the health selection of the work force. If those who leave the industry have the most severe symptoms and the highest exposure, an underestimation of the relationship between length of exposure and symptoms can occur.

If symptoms accelerate with age, other factors like duration of employment, which correlates with aging, could spuriously "pick up" this acceleration in symptoms with age. However, by means of stratified analysis, the odds ratios for symptoms in our long-term exposure group appeared to be the same for subjects over and under 40 years of age. In addition, the narrow confidence intervals for the odds ratios for duration of employment in the multivariate analysis indicate that the collinearity between age and duration of employment played a minor role in the logistic regression model.

Another objection to the finding that respiratory symptoms increased with years of employment is that preemployment selection could have changed over time and led to incomparability between the groups with long and short duration of employment. We have no information supporting this argument. The crosssectional design is inappropriate to address this question. Periodic examinations of subjects, including examinations of workers who quit, would be a better way to solve the problem.
We found a nonsignificant association for current exposure to fluorides and total dust with work-related asthmatic symptoms. This result is in contrast with the finding of Midttun (4), who noted that an excessive potroom fluoride concentration was associated with symptoms and implicated an organic fluorine-containing compound as the causative agent. This suggestion, however, has not been refined or refuted later. From two plants Maestrelli et al (25) reported five cases of potroom asthma, and in all cases the worker worked in the plant with the highest levels of hydrogen fluoride, particulate fluoride, and sulfur dioxide in the potroom air.

Our failure to detect any positive association between respiratory symptoms and total fluoride concentration may result from a relocation of workers with respiratory symptoms away from the worst-exposed jobs. For the present survey only a few plants had differentiated between gaseous and particulate fluorides. Our analyses only included total fluorides, while the use of gaseous and particulate fluoride as separate variables in the analyses could have been more relevant. In the longitudinal part of our survey we will avoid the selection bias and include more relevant exposure data. The lack of a significant association between symptoms and total dust exposure could have been due to a similar selection bias.

Although an investigation of the development of chronic respiratory disease was not a main objective of our survey, work-related asthmatic symptoms with chronic cough represent a more chronic health problem. The increased prevalence of work-related asthmatic symptoms with chronic cough with increasing length of employment indicates that long-term potroom exposure could be a risk factor for chronic respiratory disorders. The large confidence interval for the odds ratio and the significant relationship between age and work-related asthmatic symptoms with chronic cough makes this association more uncertain. As in other populations, smoking was found to be a stronger predictor than the other factors for symptoms with chronic cough.

The inhalation of pollutants depends on the use of airway protection. We observed that the regular use of respirators was positively associated with the occurrence of airway symptoms. A plausible explanation for this observation is that symptoms encourage the use of respiratory protection.

A few authors have suggested that potroom asthma is associated with a history or family history of allergy $(26,27)$. We found that a positive family history of asthma was a significant determinant of workrelated asthmatic symptoms, whereas a positive history of allergy seemed less important. It is possible that the association between familial disposition and asthmatic symptoms may in part reflect a recall bias. For instance, those who have asthmatic symptoms may be more aware of such problems among other family 
members than those who have no respiratory problems.

A misclassification of allergy will decrease the association between respiratory symptoms and allergy. Allergy was the least common in the group with long exposure, and therefore it is possible that health selection had occurred. Nevertheless, allergy probably plays a minor role as a determinant of work-related asthmatic symptoms in potroom workers and is in accordance with the findings of Sarić et al (23). In addition Midttun (4) found that skin tests with house and potroom dust were negative for asthmatic potroom workers, and skin tests for common allergens have not provided evidence of an allergic basis $(25,28)$.

\section{Association between airflow limitation and exposure}

The determinants of lung function deterioration appear to be the same as for respiratory symptoms. Both intermediate (5-9 years) and long ( $\geq 10$ years) exposure were significantly associated with airflow limitation. Current smoking and a family history of asthma were also predictors of a decline in lung function, while allergy was not.

Discher \& Breitenstein (12) found that an abnormal $\mathrm{FEV}_{1.0}$ was more common among potroom workers than it was among age- and smoking-matched referents, but the difference was not statistically significant. An association between long-term potroom exposure and ventilatory impairment has also been reported by Trichopoulos \& Limos (29), while Chan-Yeung et al (10) found a relationship of $\mathrm{FEV}_{1.0}$ and $\mathrm{FEF}_{25-75}$ with age, height, smoking, and work exposure, but not with duration of exposure. In addition, a longitudinal study has failed to show any difference in annual ventilatory decline in potroom workers in a comparison with office workers, but the loss to follow-up was $30 \%$ (30). The observation that spirometric results decline faster than average (ie, are lower in the group with the longest duration of employment) could be due to smoking rather than to other exposure. However, only $16 \%$ of the men over 50 years of age in the reference material were never smokers, and this value is fairly comparable to the prevalence of never smokers $(17 \%)$ in our study group. Although the close correlation between the variables constitute a situation in which it is difficult to distinguish between the effects of potroom employment and those of aging or smoking, the various analyses indicate that duration of employment did affect the $\mathrm{FEV}_{1.0}$ decline. As in other studies $(24,31)$, we failed to find any significant association between current exposure to total fluorides and dust and airflow limitation. The same considerations that we proposed for the negative findings of current exposure and respiratory symptoms are also valid in this respect.

\section{Concluding remarks}

Our results suggest that work-related asthmatic symptoms occur in potroom workers. Both respiratory symptoms and ventilatory impairment were related to duration of employment. On the whole, the direction of bias in our results was probably towards an underestimation rather than an overestimation of exposure effect. The effect of specific pollutants should be further investigated by a more precise exposure classification and other exposure indices (eg, number of peak levels). The effect of selection bias will probably be elucidated in the longitudinal part of our survey.

\section{Acknowledgments}

The valuable assistance, comments, and constructive criticism of the plant physicians are gratefully acknowledged. We thank the plant nurses who examined the workers and the primary aluminum industry, both employers and employees, for their considerable cooperation. We are also grateful to $\mathrm{Mr} \mathrm{OO}$ Aalen for his statistical advice and $\mathrm{Mr} \mathrm{H}$ Kjuus, Mr E Nordheim, and $\mathrm{Mr} \mathrm{V}$ Søyseth for their valuable comments on this manuscript.

This study was supported by grants from The Nordic Aluminum Industry's Secretariat for Health, Environment and Safety (AMS).

\section{References}

1. International Agency for Research on Cancer. Polynuclear aromatic compounds: part 3 . industrial exposures in aluminium production, coal gasification, coke production, and iron and steel founding. Lyon: International Agency for Research on Cancer, 1984. (Evaluation of carcinogenic risk of chemicals in humans; vol 34.)

2. Abramson MJ, Wlodarczyk JH, Saunders NA, Hensley MJ. Does aluminum smelting cause lung disease. Am Rev Respir Dis 1989;139:1042-57.

3. Frostad EW. Fluorforgiftning hos norske aluminiumsfabrikkarbeidere [Fluorine intoxication in Norwegian aluminum plant workers]. Tidsskr Nor Laegeforen 1936; 56:179-82.

4. Midttun $\mathrm{O}$. Bronchial asthma in the aluminum industry. Acta Allergol 1960;15:208-21.

5. Field GB, Milne J. Occupational asthma in aluminum smelters. Aus N Z J Med 1975;5:475-83.

6. Sarić M, Zuskin E, Gomzi M. Bronchoconstriction in potroom workers. Br J Ind Med 1979;36:211-5.

7. Field GB. Pulmonary function in aluminum smelters. Thorax 1984;39:743-51.

8. Wergeland E, Lund E, Waage JE. Respiratory dysfunction after potroom asthma. Am J Ind Med 1987;11: $627-36$.

9. O'Donnell TV, Welford B, Coleman ED. Potroom asthma: New Zealand experience and follow-up. Am J Ind Med 1989;15:43-9.

10. Chan-Yeung M, Wong R, Maclean $L$, et al. Epidemiologic health study of workers in an aluminum smelter in British Columbia. Am Rev Respir Dis 1983;127: 465-9.

11. Kaltreider NL, Elder MJ, Crawley LV, Colwell MO. Health survey of aluminum workers with special ref- 
erence to fluoride exposure. J Occup Med 1972;14: $531-41$.

12. Discher DP, Breitenstein BD. Prevalence of chronic pulmonary disease in aluminum potroom workers. $\mathrm{J}$ Occup Med 1976;18:379—86.

13. Larsson K, Eklund A, Arns R, et al. Lung function and bronchial reactivity in aluminum potroom workers. Scand J Work Environ Health 1989;15:296-301.

14. Kongerud J, Vale JR, Aalen OO. Questionnaire reliability and validity for aluminum potroom workers. Scand J Work Environ Health 1989;15:364-70.

15. British Medical Research Council, Committee on the Aetiology of Chronic Bronchitis. Standardized questionnaire on respiratory symptoms. Br Med J 1960;2:1665.

16. Gardner RM, Baker CD, Broennle AM, et al. ATS statement - Snowbird workshop on standardization of spirometry. Am Rev Respir Dis 1979;119:831-8.

17. Gulsvik A. Obstructive lung disease in an urban population [Doctoral dissertation]. Oslo: University of Oslo, 1979: $225 \mathrm{p}$.

18. Miller MR, Pincock AP. Predicted values: how should we use them? Thorax 1988;43:265-7.

19. Norusis MJ. SPSS/PC +, V 3.0 statistical package for the social sciences. Chicago, IL: SPSS Inc, 1989.

20. Baker RJ, Nelder JA. The GLIM system: generalized interactive modelling. Oxford: Royal Statistical Society, 1987. (Release 3.77.)

21. Greenberg RS, Kleinbaum DG. Mathematical modeling strategies for the analysis of epidemiologic research. Ann Rev Public Health 1985;6:223-45.

22. Rothman KJ. Modern epidemiology. 1st ed. Boston, MA/Toronto: Little, Brown and Company, 1986:31126.

23. Sarić M, Godnić-Cvar J, Gomzi M, Stilinović L. The role of atopy in potroom workers asthma. Am J Ind Med
1986;9:239- 42.

24. Clonofero E, Mastrangelo G, Cortese MS. Cross sectional study on chronic bronchitis and airflow obstruction in three Italian aluminum smelting plants. Med Lav 1981;72:301-5.

25. Maestrelli P, Marcer G, Clonofero E. Occupational asth$\mathrm{ma}$ in the aluminum industry. Eur J Respir Dis 1981; 62(suppl 113):92-3.

26. Constantopaidos F. Aluminum respiratory disorders at Saint Nicholas Aluminum de Grece. In: Coulon J-P, ed. Seminar on aluminum respiratory disorders. St Nicholas Aluminum, Greece. Paris: Aluminum Penchiney, 1980:81-90.

27. Van Voorhout HC. The respiratory condition of potroom workers: Netherlands experience. In: Hughes JP, ed. Health protection in primary aluminum production. London: International Primary Aluminum Institute, 1977:91-4.

28. Smith MM. The respiratory condition of potroom workers: Australian experience. In: Hughes JP, ed. Health protection in primary aluminum production. London: International Primary Aluminum Institute, 1977:7986.

29. Trichopoulos D, Limos A. Preliminary report on the study of lung function of workers employed in a large aluminum reduction plant. London: International Primary Aluminum Institute, 1986. (Report to the International Aluminum Institute Health Committee.)

30. Chan-Yeung M, Enarson DA, MacLean L. Longitudinal study of workers in an aluminum smelter. Arch Environ Health 1989;44:134-9.

31. Lie A, Waage JE. Pulmonary symptoms and spirometric changes among potroom workers in the aluminum industry. Oslo: National Institute of Occupational Health, 1982:870.

\section{Appendix}

\section{Models used in the multiple logistic regression}

Model 1. The full logistic regression model used to examine the interaction between smoking and exposure, and between exposure variables was of the form:

$P(Y)^{*}=1 /\left\{1+\exp \left[-\left(b_{0}+b_{1}\right.\right.\right.$ age $+b_{2}$ sex $+b_{3}$ allergy $+b_{4}$ familial asthma $+b_{5}$ use of airway protection $+b_{6}$ years of employment $+b_{7}$ dust $+b_{8}$ fluorides $+b_{9}$ technology $+b_{10}$ empldurxsmoke $+b_{11}$ empldurxdust $+b_{12}$ empldurxfluor $+b_{13}$ dustxsmoke $+b_{14}$ fluorxsmoke)]\}. [ ${ }^{*} \mathrm{P}(\mathrm{Y})$ is the probability for respiratory disease $]$

Model 2. The restricted model for the estimation of odds ratios [(exp(b)] shown in table 5 was of the form:

$P(Y)=1 /\left\{1+\exp \left[-\left(b_{0}+b_{1}\right.\right.\right.$ age $+b_{2}$ sex $+b_{3}$ allergy $+b_{4}$ familial asthma $+b_{5}$ use of airway protection $+b_{6}$ years of employment $+b_{7}$ dust $+b_{8}$ fluorides $+b_{9}$ technology)]

Model 3. The final restricted model for the estimation of odds ratios [exp(b)] shown in table 4 was of the form: $P(Y)=1 /\left\{1+\exp \left[-\left(b_{0}+b_{1}\right.\right.\right.$ age $+b_{2}$ sex $+b_{3}$ allergy $+b_{4}$ familial asthma $+b_{5}$ use of airway protection $+b_{6}$ years of employment)]\} 